\title{
Increasing 'Bradford' Pear Crotch Angles and Lateral Shoot Counts with Benzyladenine or Promalin Sprays
}

\author{
Gary J. Keever ${ }^{1}$, WJ. Foster ${ }^{2}$ J.W. Olive ${ }^{3}$, and Mark S. West ${ }^{4}$ \\ Department of Horticulture, Alabama Agricultural Experiment Station, Auburn \\ University, AL 36849-5408
}

\section{Additional index words. cytokinin, gibberellin, Pyrus calleryana}

'Bradford' pear (Pyrus calleryana Decne.), one of the most widely planted ornamental trees in U.S. Dept. of Agriculture zones 5 to 8, is characterized by an oval-to-pyramidal form and dense, ascending branches. With age, many symmetrical specimens split. Pruning during nursery production to remove narrow, barkembedded, structurally weak crotches and increase branch spacing has had limited success in alleviating splitting (Dirr, 1990). Growth regulators, such as the cytokininbenzyladenine (BA) or the combination of gibberellins and BA (Promalin; Abbott Laboratories, North Chicago, Ill.) have improved plant structure of several fruit tree species by stimulating branching and increasing primary branch crotch angles (Greene and Miller, 1988; Keen et al., 1989; Williams and Billingsley, 1970). The objective of this study was to determine the effects of foliar-applied BA and Promalin on 'Bradford' pear branching and crotch angles.

'Bradford' pear liners ( $23 \mathrm{~cm}$ long) were transplanted on 22 Mar. 1988 into 11.3-liter pots of 3 pine bark: 1 peatmoss $(\mathrm{v} / \mathrm{v})$ amended with (in $\mathrm{kg} \cdot \mathrm{m}^{-3}$ ) 3.6 dolomitic limestone, 1.2 gypsum, 0.9 Micromax (Grace-Sierra, Milpitas, Calif.), and 8.3 Osmocote $17 \mathrm{~N}-3 \mathrm{P}-$ 10K (Grace-Sierra). Plants were placed outdoors in full sun in Mobile, Ala., and maintained under overhead irrigation. On 20 Sept. 1988 , plants were pruned to $130 \mathrm{~cm}$ high and leaves were left on only the uppermost 10 nodes. The following foliar spray treatments were applied to the upper $30 \mathrm{~cm}$ of shoots: 150 , 300 , or $450 \mathrm{mg} \mathrm{BA} /$ liter or 300,600 , or $900 \mathrm{mg}$ Promalin/liter with Buffer X surfactant at $0.2 \%$. A nontreated control was included for comparison. Trees were randomized completely with six single-plant replicates. Plant height, lateral shoot count ( $>2 \mathrm{~cm}$ long) and lengths, and crotch angles were recorded on 18 Nov. 1988. The experiment was repeated in 1989

Received for publication 25 Sept. 1992. Accepted for publication $8 \mathrm{Feb}$. 1993. The cost of publishing this paper was defrayed in part by the payment of page charges. Under postal regulations, this paper therefore must be hereby marked advertisement solely to indicate this fact.

'Associate Professor of Horticulture.

${ }^{2}$ Former Superintendent. Current address Ornamental Horticulture Substation, Mobile, AL 36689. ${ }^{3}$ Superintendent.

${ }^{4}$ Assistant Professor of Research Data Analysis. with the following changes: liners were transplanted on 20 Apr., treatments were applied 12 Sept., the upper $8 \mathrm{~cm}$ of terminal shoots and leaves below the uppermost remaining 10 nodes were removed, BA at $600 \mathrm{mg} \cdot$ liter $^{-1}$ and Promalin at $1200 \mathrm{mg} \cdot$ liter $^{-1}$ were included as additional treatments, and data were collected in Dec. 1989.

Lateral shoot counts and crotch angles increased in both years with increasing concentrations of BA or Promalin (Table 1). The increase in shoot count was $65 \%$ to $440 \%$ (1988) and $43 \%$ to $174 \%$ (1989) with BA concentrations $\geq 300 \mathrm{mg} \cdot$ liter $^{-1}$, and $240 \%$ to $490 \%$ (1988) and $43 \%$ to $239 \%$ (1989) with Promalin concentrations $\geq 300 \mathrm{mg} \cdot$ liter $^{-1}$. Almost all new lateral shoots developed from the $30-\mathrm{cm}$ section of shoot treated with BA or Promalin. Crotch angles increased $26 \%$ to $30 \%$ (1988) and $10 \%$ to $26 \%$ (1989) with BA and $26 \%$ to $34 \%$ (1988) and 6\% to $38 \%$ (1989) with Promalin. Promalin resulted in more shoots $(9.6$ vs. $5.3,1988 ; 4.9$ vs. $3.9,1989)$ and greater crotch angles $\left(58^{\circ}\right.$ vs. $\left.52^{\circ}, 1988\right)$ than BA. Mean lateral shoot lengths decreased linearly in 1989 but increased in 1988 (data not shown) from $9 \%$ to $23 \%$ with BA and $15 \%$ to $57 \%$ with Promalin. The reduction was most evident for BA and Promalin at concentrations $\geq 450 \mathrm{mg} \cdot$ liter $^{-1}$ and $900 \mathrm{mg} \cdot \mathrm{liter}^{-1}$, respectively. Mean shoot lengths of BA- and Promalin-treated trees were 9.1 and $7.8 \mathrm{~cm}$, respectively, and lateral shoot length of control plants averaged $11.1 \mathrm{~cm}$. Greene and Miller (1988) reported that reducing the number of lateral shoots by pinching apexes of shoots soon after applying BA effectively increased the length of BA-induced lateral shoots. Plant heights were not affected by treatments in either test.

This research supports previous research in which lateral shoot development (Cody et al., 1985; Keen et rd., 1989; Williams and Billingsley, 1970) and crotch angles increased (Cody et al., 1985; Greene and Miller, 1988; Williams and Billingsley, 1970) and lateral shoot length decreased (Greene and Miller, 1988 ) in fruit trees when BA or Promalin was applied. Our results indicate that BA and Promalin can increase 'Bradford' pear crotch angles and potentially lessen the splitting of older trees. Increased lateral development may require selective pruning to avoid branch crowding as trees mature.

\section{Literature Cited}

Cody, C.A., F.E. Larsen, and R. Fritts, Jr. 1985 Stimulation of lateral branch development in tree fruit nursery stock with $\mathrm{GA}_{4+7}+\mathrm{BA}$. HortScience 20:758-759.

Dirr, M.A. 1990. Manual of woody landscapeplants. 4th ed. Stipes Publishing, Champaign, Ill.

Greene, D.W. and P. Miller. 1988. Effects of growth regulator sprays and notching on growth and branching of 'Starkrimson Delicious' apple trees. J. Amer. Soc. Hort. Sci. 113:18-23.

Koen, T.B., K.M. Jones, and M.J. Oakford. 1989. Promoting branching in young trees of apple cv. Red Delicious using growth regulators. J. Hort. Sci. 64:521-525.

Williams, M.W. and H.D. Billingsley. 1970. Increasing the number and crotch angles of primary branches of apple trees with cytokinins and gibberellic acid. J. Amer. Soc. Hort. Sci. 95:649-451.

Table 1. Effects of BA and Promalin on 'Bradford' pear tree primary shoot development.

\begin{tabular}{|c|c|c|c|c|c|}
\hline \multirow[b]{2}{*}{ Treatment } & \multicolumn{2}{|c|}{$\begin{array}{c}\text { Lateral } \\
\text { shoot }^{2} \\
\text { (no.) }\end{array}$} & \multicolumn{2}{|c|}{$\begin{array}{c}\text { Crotch } \\
\text { angle } \\
\text { (degree) }\end{array}$} & \multirow{2}{*}{$\begin{array}{c}\begin{array}{c}\text { Mean lateral } \\
\text { shoot length } \\
(\mathrm{cm})\end{array} \\
1989\end{array}$} \\
\hline & 1988 & 1989 & 1988 & 1989 & \\
\hline$\overline{\text { Control }}$ & 2.0 & 2.3 & 45 & 46 & 11.1 \\
\hline \multicolumn{6}{|l|}{ BA (mg.liter $\left.{ }^{-1}\right)$} \\
\hline 150 & 1.8 & 2.3 & 42 & 51 & 10.1 \\
\hline 300 & 3.3 & 3.3 & 57 & 50 & 10.7 \\
\hline 450 & 10.8 & 3.5 & 58 & 59 & 6.9 \\
\hline 600 & --- & 6.3 & --- & 58 & 8.6 \\
\hline \multicolumn{6}{|l|}{ Significance } \\
\hline Linear & $* *$ & $* *$ & $* *$ & $*$ & $*$ \\
\hline Quadratic & $*$ & NS & NS & NS & NS \\
\hline \multicolumn{6}{|l|}{ Promalin (mg.liter ${ }^{1}$ ) } \\
\hline 300 & 6.8 & 3.3 & 57 & 49 & 9.4 \\
\hline 600 & 10.3 & 2.8 & 58 & 49 & 10.8 \\
\hline 900 & 11.8 & 6.0 & 60 & 61 & 6.1 \\
\hline 1200 & --- & 7.8 & --- & 63 & 4.8 \\
\hline \multicolumn{6}{|l|}{ Significance } \\
\hline Linear & $* *$ & $* *$ & $* *$ & $* *$ & $* *$ \\
\hline Quadratic & NS & $*$ & NS & NS & NS \\
\hline BA vs. Promalin & & $*$ & & NS & NS \\
\hline
\end{tabular}

${ }^{2}$ Shoots $>2 \mathrm{~cm}$ long were counted.

${ }^{v s, *, * z}$ Nonsignificant or significant at $P \leq 0.05$ or 0.01 , respectively control included in regression analyses. 